\title{
Quality Brood Stock Development for Kolleru Carp Cultures in Andhra Pradesh, India
}

\author{
T. Suguna* and J. Yaswanth Kumar \\ Fisheries Research Station, SVVU, Undi, W.G.Dt, Andhra Pradesh, India \\ *Corresponding author
}

\section{A B S T R A C T}

\section{Keywords}

Indian major carps,

Brood stock,

Development,

Management

strategies

\section{Article Info}

Accepted:

10 August 2020

Available Online:

10 September 2020
Andhra Pradesh is the model and leading semi intensive carp culture (Kolleru carp culture) state in India. It is also recognized as a world class aquaculture site. In course of expansion and identification of the semi intensive Indian major carp over more than three decades, many economically important problems have been persistently identified which are threatening sustainability of the culture system. One of the most important of these is "deterioration of the brood stock and seed quality of Indian major carps. This is due to unscientific and improper brood stock selection, management and inbreeding depression which leads to retarded growth, poor reproductive performance, morphological deformities, increased incidence of diseases and mortality. The farmers of Andhra Pradesh determined to replace this lower quality seed with good genetic quality produced from genetically sound brood stock, to overcome the economic loss. For any sustainable and successful aquaculture, quality seed is the fundamental prerequisite, which in turn depends on quality of brood stock. The development and management of brood stock of Indian Major Carps is the need of the hour as they project major part of freshwater aqua production in this region. So it is the most important one to be tackled immediately to meet the need of the farmer, aqua industry and simultaneously the sustainability of the culture.

\section{Introduction}

India is the second largest producer of fish in the world, accounting for $6.56 \%$ of global production. Besides providing livelihood and employment, its export earnings from the sector has crossed 45,000 (foreign exchange) during 2017-18. The annual growth rate is over $7 \%$ since last few years. Though aquaculture is practiced both at Freshwater and coastal environment, more than $80 \%$ of production comes from Fresh water aquaculture. Indian major carps comprising
Catla catla, Labeo rohita and Cirrhinus mrigala contribute to nearly $80 \%$ of Fresh water aquaculture production. Andhra Pradesh state has emerged as the leading semi-intensive carp culture state in India. Labeo rohita contributes to $80-90 \%$ of the total Indian major carp production (0.8 million tonnes) in the state. The rest of the production is mostly contributed by Catla catla. In spite of the unprecedented development of semi intensive major carp culture in Andhra Pradesh, many economically important problems have been 
identified, that are threatening the sustainability of the culture systems. One of these is degraded quality of the brood stock and seed of the Indian major carps. Earlier to 1985, Andhra Pradesh was dependent on West Bengal for seed requirement. But now became self sufficient and emerged as the third largest fish seed producer, catering to the needs of about 7 other Indian states for culture or for stock enhancement of natural water bodies. But with the advent of the culture using yearlings as seed for grow out culture, the culture ponds became the source of brood stock for seed production by hatcheries.

This has been the case for rohu especially as females of rohu also mature at the end of second year, i.e. by the time of the pond harvest. With this practice, selection and maintenance of rohu broodstock on sound genetic principles almost became extinct. Importantly, rohu forms the major component of the total pond cultured major carps in Andhra Pradesh. Similar change has taken place in case of Catla brood stock selection also, to some extent.

The reasons for improper culture are: 1 . Currently there is no practical intervention in selection of brood stock and the procedure is random, which does not fallow sound genetic principles. 2. The density in the culture ponds is usually high, but brood stocks are to be reared at a far lower density to reduce the stress related diseases. 3. Usually fish in culture pond are fed with antibiotics and other drugs to control bacterial and parasitic diseases and they are often under severe stress of low dissolved oxygen etc., hence there is every possibility that the quality of the eggs of the brood stock and consequently seed quality is negatively affected. 4. There is no control on the size and age of the brood stock used for seed production and their sized age is also as critical factor. In the recent years, Indian major carp farmers in Andhra Pradesh are of the firm opinion, based on their practical experience that they are unable to achieve profitable crops due to inferior seed quality and hence their economic losses are aggravating. The farmers are now determined to stock seed produced from quality brood stock only. In this context, quality brood stock of good genetic quality is undertaken to rear and develop brood stock of good genetic quality and supply to needy selected farmers and hatchery owners to ensure supply of quality seed to farmers. This intervention will ensure supply of quality seed to other Indian states also.

The quality and reliable supply of healthy seed (spawn, fry and fingerlings) with sound genetic base is largely dependent on the successful collection, stocking, rearing and management of brood fish which are the most important parts of aquaculture activities.

\section{Brood stock management}

Brood stock selection and management is a very crucial aspect in fish culture; as quality fish seed is the foundation for sustainable success of any fish culture programme. The quantity and quality of the seed is dependent on the quality of brood stock. The brood stock management is not seasonal and confined to breeding season only but exceeds as, a round the year management practice. Brood stock development covers various aspects like survey (for genetic quality breeder's) and selection of brood stock of specific number, size, age, collection and quarantine. The Brood stock management involves several steps as, selection, collection, pond preparation, stocking, rearing, nutrition feed and feed management, water quality and health management, the important recommendations and guidelines for improved brood stock management to obtain seed with high genetic quality are as below framed (Fig. 1-6). 


\section{Source of future breeders}

A minimum base preparation of each specific selected (Catla, Rohu and Mrigala) species should be surveyed and collected from various riverine systems or from the National brood banks.

In this study, wild seed is collected from the Gangetic riverine areas. The pockets like Guptipada (Hooghly dt), Katwa (Badwan dt), Lalgola (Mushidabad dt), Farakka (Mushidabad dt), and Triveni (Hooglydt) of river Ganga are identified as seed resources. With the assistance of the local fishermen and the scientists of CIFRI, Barrackpore, West Bengal wild seed is collected and is stocked temporarily in the nursery ponds of CIFRI Barrackpore, West Bengal.

\section{Transportation of seed}

Every measure is taken for attaining maximum survivality and lessen transport mortality.

\section{Nursery management}

Pond preparation: Nursery ponds of size 0.10.6 acre are ideal. The basic steps in the preparation of pond like, control of aquatic weeds, eradication of unwanted fish applying mahua oil cake $800-1000 \mathrm{~kg} /$ acre and pond liming at $30-50 \mathrm{~kg} / \mathrm{acre}$ depending on the $\mathrm{ph}$ of soil and water. This is followed by fertilizing the pond with cattle dung @ 6000$8000 \mathrm{~kg} / \mathrm{acre} / \mathrm{yr}$ or poultry manure @ 2000$4000 \mathrm{~kg} / \mathrm{acre} / \mathrm{yr}$. In addition 60$80 \mathrm{~kg} / \mathrm{acre} /$ year NPK mixture is applied in split doses at fortnight of monthly intervals.

Stocking density: 80,000-1,00,000/acre

Water Quality Management: water depth of 1$1.25 \mathrm{~m}$ is maintained.
Nutrition, Feed and Feed Management: ground nut cake (10-12 kg/acre), raw rice bran, deoiled rice bran.

Health Management: for every fortnight sampling is done to analyse the water quality parameters and also monitoring of the health status.

Harvesting: 2.0-2.5 cms, 0.5-1.0 gms@ 30 days is done.

\section{Rearing management}

Pond size: $1.0-10.0$ acres

Pond preparation: The pond preparation, manuration and fertilization practices that are used to promote natural food production are similar to those used during the nursery production phase. The exception is the increased use of organic and inorganic fertilizers. In terms of organic manure, upto $1600 \mathrm{~kg} /$ acre of poultry cattle / manure dung of $1200 \mathrm{~kg} /$ acre may be applied. A dose of $20-50 \mathrm{~kg} / \mathrm{acre}$ of DAP, $10-50 \mathrm{~kg} / \mathrm{acre}$ of urea and potash at 10-12 kg/acre may be applied. During the growing period, cattle dung is applied at rate of 400 to $800 \mathrm{~kg} / \mathrm{acre}$ and where monthly doses are given, about $108 \mathrm{~kg} / \mathrm{acre} / \mathrm{month}$ and DAP of 6$16 \mathrm{~kg} / \mathrm{acre} / \mathrm{month}$ are applied.

Stocking density: 50,000- 80,000/acre.

Water quality management: $1.25-1.50 \mathrm{~m}$

Nutrition feed and feed management: As per biomass the stock is fed with well balanced high protein diet.

Health Management: Through periodical sampling the growth performance and status are monitored

Harvesting: 20-25 gms@ 2-4 months is done. 


\section{Grow out management}

Pond size: 1.0 acre

Pond preparation: The organic fertilizers like poultry manure and cattle dung are heavily used along with the inorganic fertilizers.

Stocking density: catla: 300-350, rohu: 1000 2000/acre

Water Quality Management: Regular sampling for every fortnight.

Nutrition, feed management: As per biomass fed with high protein diet

Health Management: Regular monitoring samples are carried.

Harvesting: $1-1.25 \mathrm{~kg}$ of rohu and catla of 2$2.5 \mathrm{~kg}$

\section{Basics in selecting good future breeders}

The selection of future carp breeders should take into account the general shape of fish body, scale distribution, state of health and development of sexual organs.

In particular -1 . The selected fish should be in good health 2 . With no body wounds 3 . No parasites. 4. A typical scale distribution and 5 . No. fin or body deformation. 6. The body should possess the required shape and proportions being neither too fat nor too thin.

\section{Differentiation of male and female}

The male and female breeders may be easily differentiated by the pectoral fins, shape of the body and the relative position of the genital papilla. In females, the pectoral fins are smooth and body is plump/distended and the genital opening is pinkish and situated above the genital papillae.

In the males, the pectoral fins are rough due to the presence of "ctenoid teeth structures" prominently along the first ray body is slender and the gental opening is found behind the genital papillae. The male and females brooders should be in the ratio of 1:1 in order to maintain high effective population size for maintaining high levels of genetic diversity.

\section{Size maturity of breeders}

To check whether a carp breeder has reached maturity (presence of dormant eggs or sperm) and may be selected for artificial propagation, the belly and genital papillae should be examined carefully. A mature female has a well rounded and soft or semi soft belly, its genital papilla is erect and reddish, its anal opening is enlarged and protruding. A male will release milt under a slight abdominal pressure. Such brooders with well developed sexual organs are selected as potential spawners.

\section{Pond preparation}

The ponds are dried, ploughed, limed. The ponds should be free from aquatic weeds, weed fishes and predators. To remove/eradicate the unwanted fish pesticides like mohua oil cake (200-250 ppm) or bleaching powder (20-30 ppm chlorine level) are applied. Urea is also used at $10 \mathrm{ppm}$ in some, a day before application of bleaching powder (Ram etal.1988). Raw cow dung at rate of 2-3tons, single super phosphate of 40$100 \mathrm{~kg}$, urea $30-40 \mathrm{~kg}$, murate of potash 20 $\mathrm{kg} / \mathrm{acre} / \mathrm{yr}$ applied. Initial dose of $1 / 4^{\text {th }}$ of total is issued later the rest is used in spitted doses. The rate of fertilizer application is ascertained on soil fertility, water quality and culture practices.

\section{Size of the ponds}

Brood stock ponds should be $0.5-1.0$ and 1.5$2.5 \mathrm{~m}$ deep, 30-40 m wide, rectangular seasonal or drainable and earthen in nature. The dykes should be protected by vegetation. Water control structure exists at the inlet and outlet of the pond. Access by road and good protection against poaching should be ensured. 


\section{Stocking of brooders}

It is one of important measure for assuring good and healthy parent fish. The recommended stocking density of carp brood fish is $300-500 / \mathrm{kg} /$ acre depending upon the species while rohu and mrigala are stocked at a higher rate, Catla is stocked at a lower rate since it feeds more space for proper gonadal development. Maintain large population size for each selected species and also of equal sex ratio (50:50). To avoid stress far lower stocking density i.e. 200-400/ acre are preferred.

\section{Sampling: At regular intervals sampling is} done to monitor the brooder status and health condition

\section{Feed nutrition and feeding}

The quality of ingredients, diet, feeding regime and the management are the principal factors that influence the condition of the Broodstock. To ensure better and daily development of gonads, the fish breeders use a special brood stock diet (protein 25-30\%, proposed using locally available cheep ingredients. If the diet is nutritionally superior, advances maturation and spawning by one or two months and results in increased fecundity and better seed quality Fed at 1$2 \%$.of bodyweight, with feed of the Ingredients DOB 70\%, GNC: 5\%, soyabean cake: $10 \%$,dry fish meal:14\% and mineral and vitamin mixtures $1 \%$, Fed at 1-2\%.

Quality natural feed also plays a role in brood stock maturation. The conventional feeds generally lack essential nutrients. But nutritionally balanced feeds provide all essential nutrients which advance the gonad growth and maturation and facilitates early spawning. Ensure high production of viable eggs and sperms and enhance spent fish recovery. Also Promises higher recovery of quality of seed per unit body weight of the female, ensure better survival of seed and rapid growth during nursery rearing.

Modification in the nutrient quality of ration for better, significantly effects fecundity, the brood fish, the ability of brood fish to mature and size and quality of the eggs produced. To enhance gonadal developmental and to avoid accumulation of fat, diets rich in protein, rather than carbohydrates may be provided to brood stock round the year. The required feed protein for fish is $35 \%$, carbohydrates 30 $35 \%$, fat $5-6 \%, \mathrm{~N}-3 \%$, fatty acids $-0.5-1.0 \%$, fiber $5 \%$, moisture $<10 \%$, vitamins $0.25 \%$ and mineral mixture $0.5 \%$.

Also provision of feed in such a physical form that the feed does not disintegrate or leach nutrients. Floating pellets are most preferable.

Broodstock diet has strong influence on breeding performances also. It can influence rapid maturation of the gonad. Spawn recovery is directly dependent on brood diet composition. In balanced diet the egg sperm and larval quality were superior. Rice bran, ground nut cake, roasted soybean meal, fish meal and mineral mixture, vitamin mixture and a mixture of vegetable and fish oil, are the ingredients of feed.

Results showed that nutritional quality of the diet considerably influenced breeding performances in the species. The total number of matured females was highest in this diet and maturity was advanced by 35 days. The maximum fertilization rate, gonadal maturation breeding performances and spawn recovery. It is generally accepted that nutritionally well balanced diet are an essential prerequisite to maintaining normal immune function (Stoskoff, 1993).

\section{Age of brooders}

Brood stock size and age are the vital factors that influences the reproductive performances, 
egg quality and higher production of viable off spring. The parent fish will be of 2-3 years of age (rohu of 2 yrs and Catla of 3 years of age).

\section{Water quality parameters}

Monitoring of water quality was done at regular intervals of every 15 days. Care should be taken to maintain water quality and plankton oeveo by periodic manuring i.e. at one tenth of initial dose. Algal blooms and oxygen depletion are controlled by water exchange. Paddle wheel aerator, particularly in Catla ponds can provide additional aeration, particularly in the morning hours. The optimum water quality parameters of brood ponds are temperature:20-35oc, color: greenish. Turbidity: $8-20 \mathrm{~cm}$ visibility, $\mathrm{Ph}: 7.8-$ 8.5, D.O: 4.0-8.0ppm, Total alkalinity:80-150 ppm, NH4: $\quad 0.2-0.5 p p m, \quad$ nitrite (N02)<0.014ppm, P2o5:0.01-0.5 ppm. Each parameter of water quality should be in ideal range, if outside of this range will suffer stress, which means that a variation in one water quality parameter can influence the toxicity of other. The water quality and feed quality are to be monitored regularly for better parental stock (Table 1).

Table.1 Water quality parameters recorded:

\begin{tabular}{|c|c|c|c|c|c|c|c|c|c|}
\hline \multirow[b]{2}{*}{$\begin{array}{l}\text { Pond } \\
\text { No. }\end{array}$} & \multirow[b]{2}{*}{$\begin{array}{l}\text { Pond } \\
\text { depth } \\
\text { cm }\end{array}$} & \multicolumn{8}{|c|}{ Parameters } \\
\hline & & $\begin{array}{c}\text { Temp } \\
{ }^{\circ} \mathrm{C}\end{array}$ & $\mathrm{pH}$ & $\begin{array}{c}\text { Salin } \\
\text { ity } \\
\text { ppt }\end{array}$ & $\begin{array}{c}\text { Total } \\
\text { alkalinity } \\
\text { ppm }\end{array}$ & $\begin{array}{c}\text { Total } \\
\text { hardness } \\
\text { ppm }\end{array}$ & $\begin{array}{l}\text { DO } \\
\text { ppm }\end{array}$ & $\begin{array}{l}\text { Ammoni } \\
\text { a ppm }\end{array}$ & $\begin{array}{c}\text { Trans- } \\
\text { parency } \\
\text { cm }\end{array}$ \\
\hline 1 & 150 & $25-32$ & 7.4-8.2 & 0 & $120-140$ & $160-400$ & $5.0-6.0$ & $\mathrm{Nil}$ & $25-35$ \\
\hline 2 & 90 & $25-32$ & 7.2-8.1 & 0 & $110-150$ & $160-400$ & $5.0-6.0$ & Nil & $24-40$ \\
\hline 3 & 120 & $25-32$ & 7.4-8.2 & 0 & $110-150$ & $180-450$ & $5.0-6.0$ & Nil & $25-35$ \\
\hline 5 & 130 & $25-32$ & $7.5-8.4$ & 0 & $130-160$ & $150-430$ & $5.0-6.0$ & Nil & $22-40$ \\
\hline 6 & 120 & 25-32 & 7.7-8.3 & 0 & $120-140$ & $160-400$ & $5.0-6.0$ & Nil & $22-40$ \\
\hline 8 & 150 & $25-32$ & 7.6-8.4 & 0 & $130-140$ & $150-410$ & $5.0-6.0$ & Nil & $25-35$ \\
\hline 9 & 90 & $25-32$ & 7.7-8.3 & 0 & $120-140$ & $160-400$ & $5.0-6.0$ & Nil & $22-40$ \\
\hline 10 & 90 & $25-32$ & 7.2-8.5 & 0 & $120-140$ & $150-350$ & $5.0-6.0$ & Nil & $25-40$ \\
\hline 11 & 85 & 25-32 & 7.5-8.5 & 0 & $130-150$ & $160-380$ & $5.0-6.0$ & Nil & $20-35$ \\
\hline 12 & 150 & $25-32$ & 7.7-8.3 & 0 & $120-140$ & $140-350$ & $5.0-6.0$ & Nil & $25-40$ \\
\hline
\end{tabular}

Fig.1

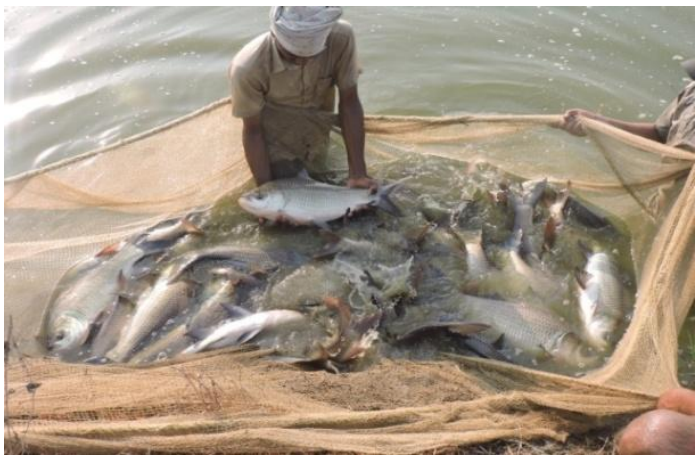


Fig.2

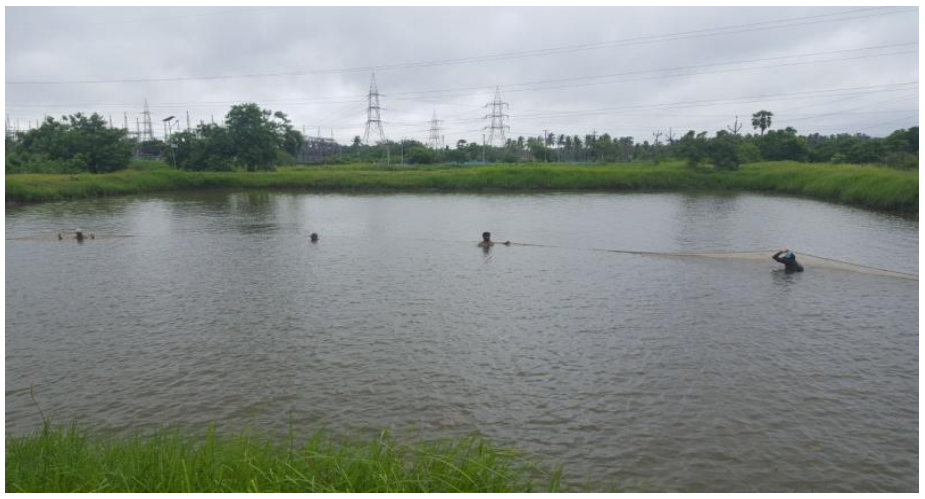

Fig.3
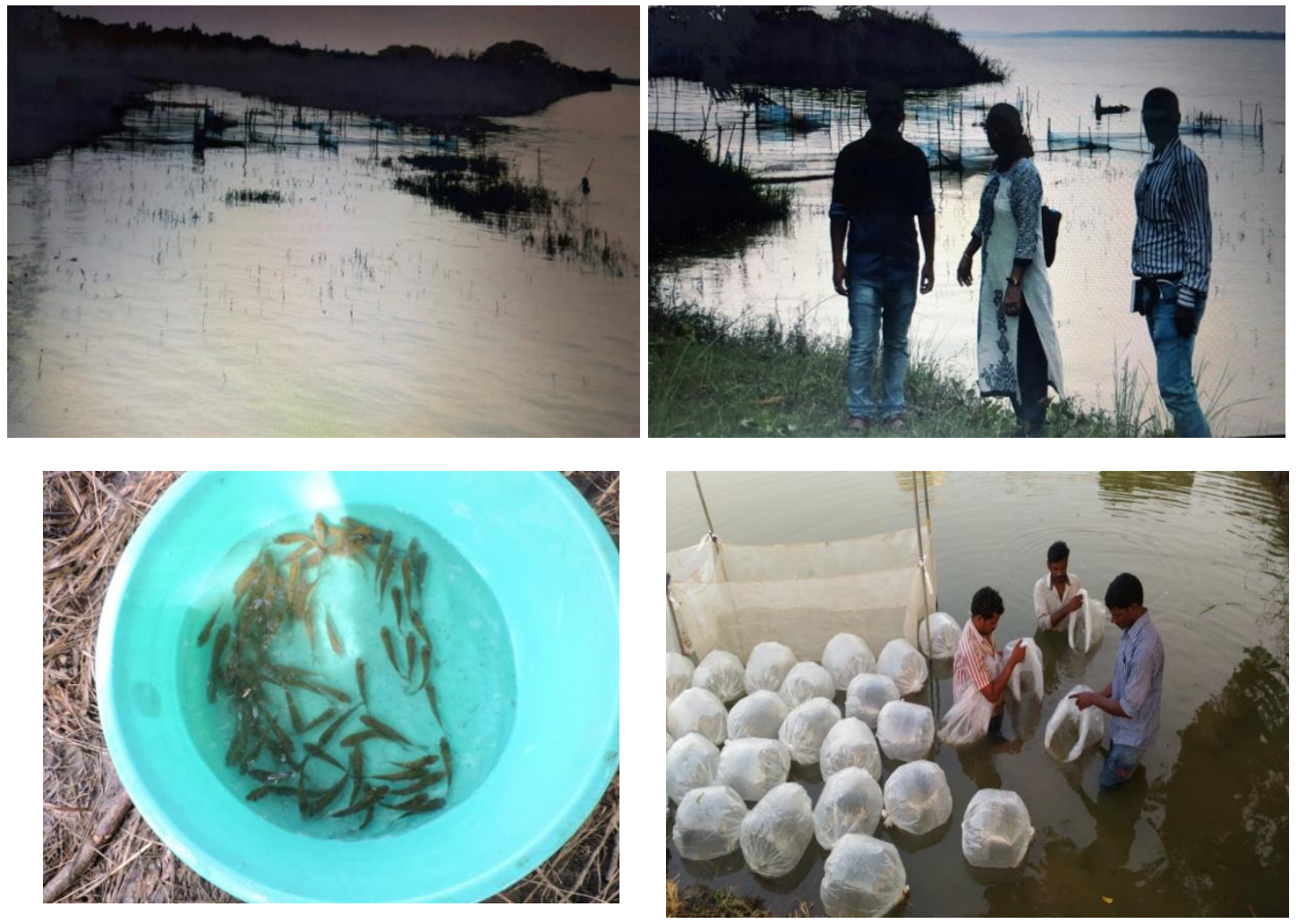

Fig.4
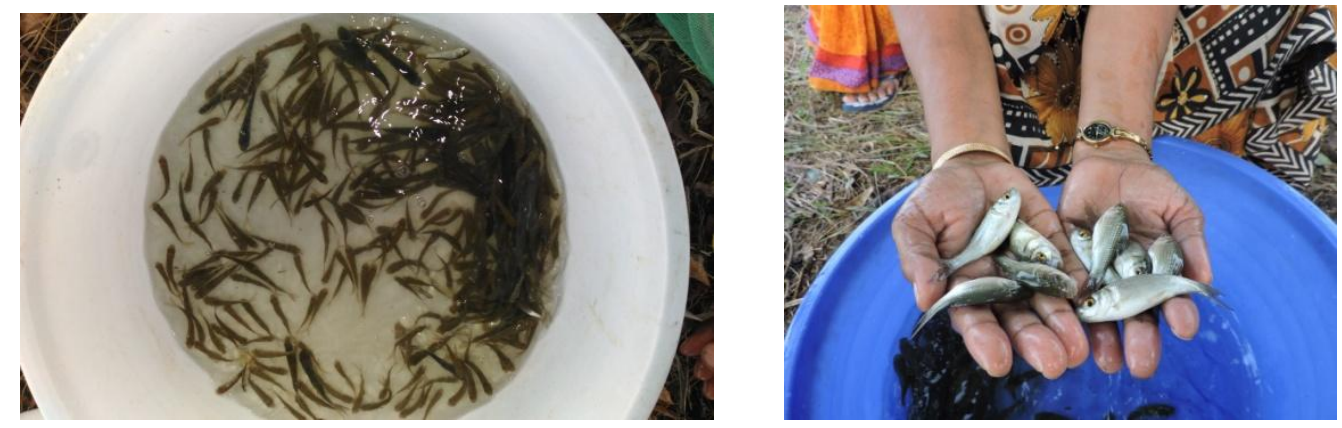
Fig.5
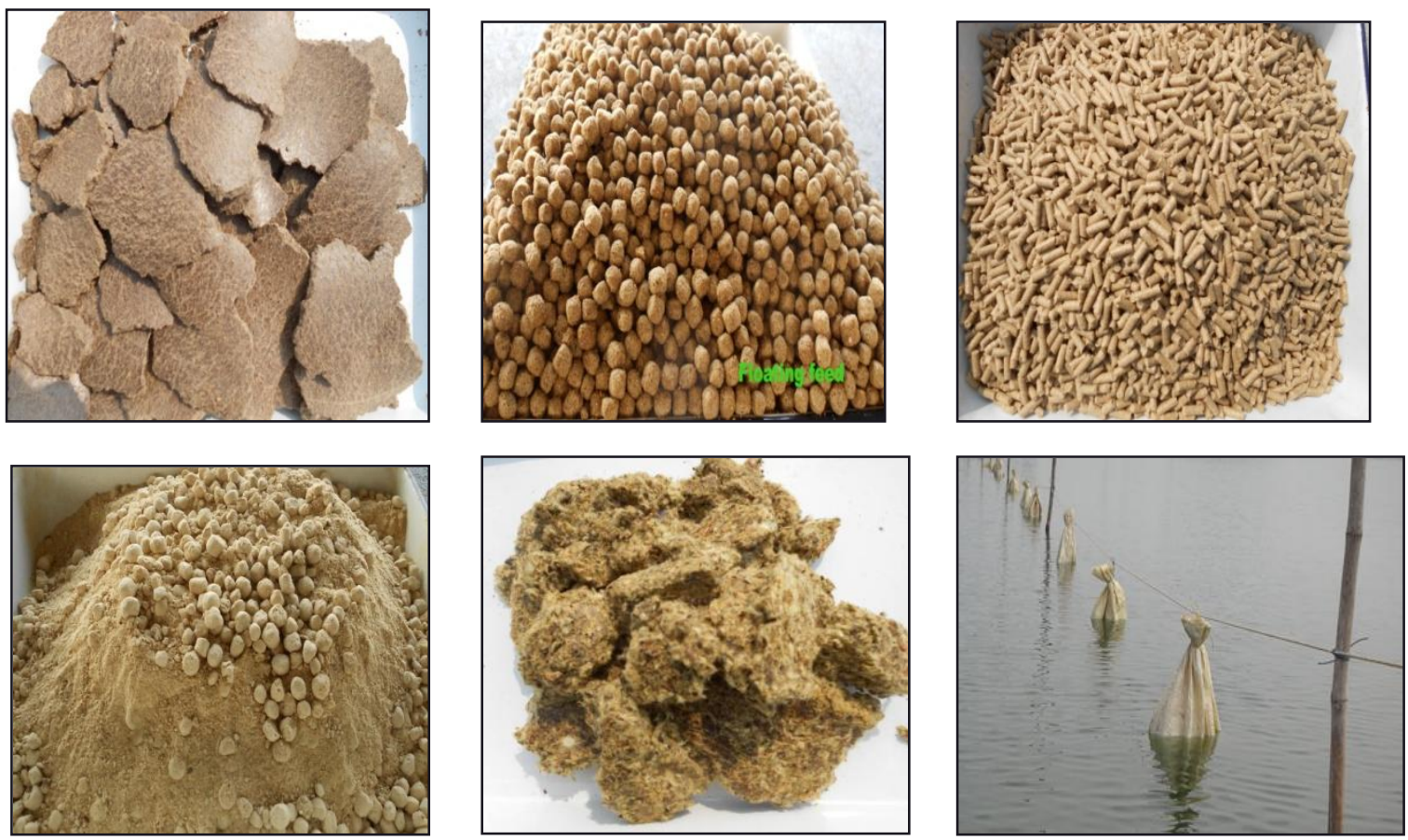

Fig.6
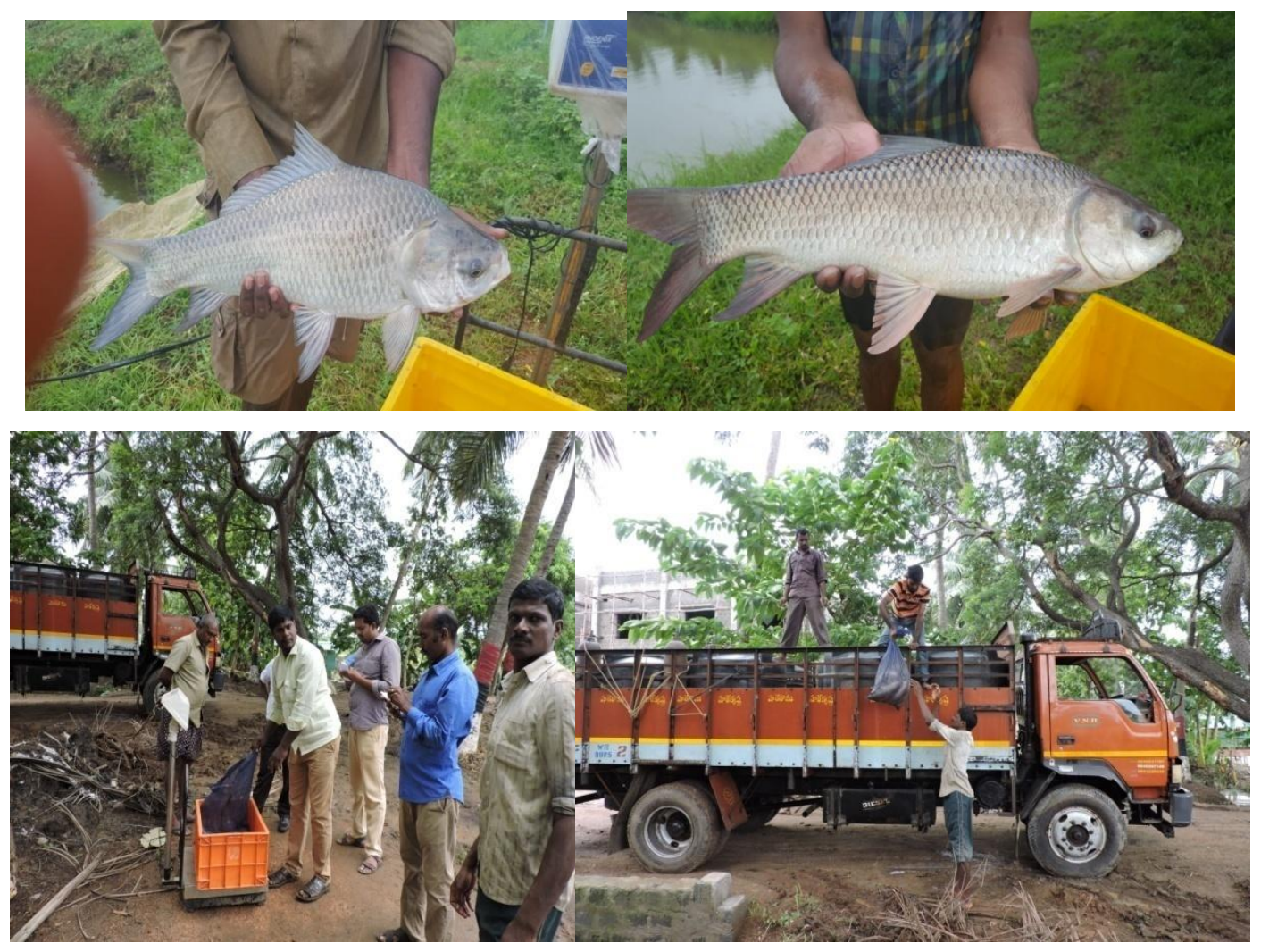


\section{Disease /health management}

Broodstock health status is important to consider as some of the dangerous pathogens are known to be transmitted both vertically and horizontally. The bacterial and common parasites like lernaea and argulus are common on major carps (catla is more susceptible) can be controlled by treating with disinfecting agents. The red disease in carp, which can result in total mortality in several days if not treated, is the major disease reported. Some parasitic infections are also common in carp ponds during nursery and grow out periods.

In conclusion, freshwater Aquaculture has been the mainstay of Indian aquaculture in terms of total quantity as well as its share to the domestic fish basket, presently contributing go over $50 \%$ of total fish production. The potential of tripling fish production has both horizontal and vertical expansion $\mathrm{n}$ terms of enhanced productivity per hectare per year. Freshwater aquaculture in India is mainly carp based (over $82 \%$ ).

The primary areas or carp pockets of Indian major carps in Andhra Pradesh are the Fish bowl of West Godavari and Krishna districts. The most high culture practice in this carp predominant area is the semi intensive culture, which is popularly known as the "Kolleru carp culture" which is recognised as world class aquaculture. In course of expansion and intensification of this semi intensive Indian major carp culture over the last three decades, the basic semi intensive poly culture has been improved a lot. Farmers have started to stock progressively larger fish, effectively shortening the culture period. This enables more production cycles to be grown over a given period i.e., Indian major carp farmers have shown an increasing interest in stocking zero point size and for breeding broodstock is selected and collected in unscientific methods, directly from culture ponds which usually stocked in high stocking densities and reared through feed with antibiotic and other drugs to control bacterial and parasitic diseases. This selection and collection of breeders has high impact on the genetic vigour of the breeder and seed later on. In order to provide sustainability in culture and production focussed efforts are required towards;

There should be practical intervention in the selection of genetically sound breeders.

The proposed broodstock should be reared in low stocking densities ever since their rearing stages.

No factor bring into stress at any stage of rearing as this effects the quality of the seed.

Broodstock size and age play a vital role in quality of seed, so sized age is a critical factor.

Along with all these the environment, rearing practices at a very stage play an important role.

Brood stock diet has strong influence on breeding performance. It can influence rapid maturation of the gonad. Spawn recovery is directly dependent on brood diet composition.

The quality seed and broodstock deterioration is due to poor broodstock management (i.e., unconscious negative selection or use of breeders of undesirable size), inbreeding and ignorance in maintenance.

As the old adage says "what you sow is what you reap", quality broodstock development is the crucial aspect for quality seed production which is the foundation for any culture and also has high socio economic impact on the livelihood of the aqua farmers..

Present paper gives a brief overview of the quality Broodstock development and Management. 


\section{References}

1. Mair, G. 2002, The supply of good quality fish seed for sustainable aquaculture: Aquaculture Asia 2002; 7 : 25-27

2. Mohan C.V 2007, FAO Fisheries Technical Paper No. 501, Rome, FAO; 625 p: pp $499-517$.

3. Stoskoff, M.K. 1993, Fish Medicine W.B. Sandurs Company, USA, 882 pp.
4. Ramakrishna $\mathrm{R}$ et al., 2013 FAO Technical paper No. 578: pp 15-40.

5. Routrey P, 2012 Carp brood stock management and quality seed production pp 22-39.

6. Status of Indian major carp seed production in India Bindu Ripiollai 132138 Indian Aquaculture 2020.

\section{How to cite this article:}

Suguna, T. and Yaswanth Kumar, J. 2020. Quality Brood Stock Development for Kolleru Carp Cultures in Andhra Pradesh, India. Int.J.Curr.Microbiol.App.Sci. 9(09): 1066-1075. doi: https://doi.org/10.20546/ijcmas.2020.909.133 